results originate in two independent centres. Leary et al suggest that as HPV DNA is not always present in glandular neoplasia ${ }^{1}$ that HPV might be a cofactor rather than an initiator of endocervical glandular neoplasia. If this is so then HPV DNA need not necessarily be detected, possibly explaining the discrepant results from the United Kingdom and elsewhere.

To summarise, results from the United Kingdom $^{37}$ suggest that infection with HPV types $6,11,16,18$ and 31 does not necessarily have a major role in cervical glandular neoplasia.

1 Leary J, Jaworski R, Houghton R. In situ hybridization using biotinylated DNA probes to human papillomavirus in adenocarcinoma in situ and endocervical glandular dysplasia of the uterine cervix. Pathology 1991;23:85-9.

2 Nicklin JL, Wright RG, Bell JR, Samaratunga H, Cox NC, Ward BG. A clinicopathological study of adenocarcinoma in situ of the cervix. The influence of cervical HPV infection and other factors, and the role of conservative
surgery. Aust NZ J Obstet Gynaecol 1991; 31:179-83.

3 Young FI, Ward LM, Brown LJR. Absence of human papillomavirus in cervical adenocarcinoma determined by in situ hybridisation. J Clin Pathol 1991;44:340-1.

4 Tase T, Okagaki T, Clark BA, et al. Human papillomavirus types and localization in adenocarcinoma and adenosquamous carcinoma of the uterine cervix: A study by in situ DNA hybridization. Cancer Res 1988;48: 993-8.

5 Tase T, Obagaki T, Clark BA, Twiggs LB, Ostrow RS, Faras AJ. Human papillomavirus DNA in adenocarcinoma in situ microinvase adenocarcinoma of the uterine cervix and coexisting cervical squamous intra epithelial neoplasia. Int J Gynecol Pathol 1989;8:8-17.

6 Farnsworth A, Laverty C, Stoler MH. Human papillomavirus messenger RNA expression in papillomavirus messenger RNA expression in adenocarcinoma in situ of the uterine

7 Griffin NR, Dockey D, Lewis FA, Wells $M$. Demonstration of low frequency of human papillomavirus DNA in cervical adenocarcinoma and adenocarcinoma in situ by the polymerase chain reaction and in situ hybridization. Int J Gynecol Pathol 1991 10:36-43.

Radiation colitis is another mimic of chronic inflammatory bowel disease

We read with great interest the article written by Shepherd. ${ }^{1}$ This informative review will be of great use to practising histopathologists when they face an avalanche of colorectal biopsy specimens with relatively little clinical information. The article should persuade both pathologists and physicians that clinical information is of great importance in reaching a histological diagnosis. The colorectal mucosa has limited ways of expressing itself in response to injury - a single brick from the Berlin Wall may look identical to one from the longstanding Wall of China.

The article does not define the histological features of chronic inflammatory bowel disease, but this diagnosis must be based on a combination of several morphological features such as crypt distortion, metaplasia (Paneth cells or pseudopyloric), fibrosis of the lamina propria associated with loss of crypts and/or significant increase in chronic inflammatory cells. On this basis we believe that radiation colitis is an important addition to the diagnostic possibilities. Radiotherapy is a common form of treatment for many pelvic carcinomas and the clinical features of radia- tion enteropathy may appear after many years when the inheriting surgeon may be unaware that the patient has been irradiated. Radiation colitis in the chronic phase demonstrates a very significant crypt distortion, vascular telangiectasia, and fibrosis of the lamina propria, which can easily be misinterpreted as healed or quiescent chronic inflammatory bowel disease, unless the relevant information is available. ${ }^{2}$

NY HABOUB SM KAFTAN PF SCHOFIELD

University Hospital of South Manchester West Didsbury, Manchester M20 8LR

1 Shepherd NA. Pathological mimics of chronic inflammatory bowel disease. J Clin Pathol inflammatory bow

2 Haboubi NY, Hasleton PS. The causation and clinical management of pelvic radiation disease. Berlin: Springer-Verlag, 19-35.

\section{Oestrogen receptors in conjunctival malignant melanoma}

Paridaens et al claim to have demonstrated oestrogen receptors in paraffin wax sections of formalin fixed conjunctival malignant melanomas. ' It is not unreasonable to expect that these lesions may be susceptible to endocrine factors, but the authors' results do not support their conclusions.

I have two reservations. First, the cytoplasmic staining they observed conflicts with the known nuclear location of oestrogen receptors. ${ }^{2}$ Second, although the antibody to ER-D5 recognises an epitope on an oestrogen receptor related protein, several studies have shown that immunostaining with this reagent correlates poorly with the results of ligand binding assays for oestrogen receptors. ${ }^{3-5}$ Furthermore, the authors are mistaken to believe that ER-D5 is ". . . present only in oestrogen receptor positive tissues." 6

Finally, the statement that ". . . a nuclear binding assay, which identifies non-functional receptors, may be more appropriate" makes no sense. Surely it is more appropriate to identify functional receptors by, for example, seeking oestrogen regulated proteins, such as progesterone receptor and cathepsin D.

JCE UNDERWOOD Department of Pathology University of Sheffield Medical School Sheffield S10 2RX

1 Paridaens DA, Alexander RA, Hungerford JL, McCartney ACE. Oestrogen receptors in conjunctival malignant melanoma: immunocytochemical study using formalin fixed paraffin wax sections. J Clin Pathol 1991;44:840-3.

2 King WJ, Greene GL. Monoclonal antibodie localize oestrogen receptor in the nuclei of target cells. Nature 1984;307:745.

3 Horne GM, Angus B, Wright C, et al. Relationships between oestrogen receptor, epiderma growth factor receptor, ER-D5, and P24 oestrogen regulated protein in human breas cancer. J Pathol 1988;155:143-50.

4 Giri DD, Dangerfield VJM, Lonsdale R, Rogers $\mathrm{K}$, Underwood JCE. Immunohistology of oestrogen receptor and D5 antigen in breast cancer: correlation with oestrogen receptor cancer: correlation with oestrogen receptor by radioligand binding and enzyme immunoby radioligand binding and enzyme im

5 van der Walt LA, Phillips JI, Afrika DJ. Oestrogen receptor assay by ER-D5 immunocytochemistry fails to correlate with ligand-binding assay in breast cancer. ligand-binding assay in bre

6 Jemec GB, Wojnarowska F. The distribution of p29 protein in normal human skin. $\mathrm{Br} J$ Dermatol 1987;117:217-24.
Dr Paridaens et al comment:

We thank Professor Underwood for his comments on our paper. We disagree, however, with his statement that "the cytoplasmic staining they observed conflicts with the known nuclear location of oestrogen receptors". An alternative immunochemical approach in the detection of the receptor moiety of steroid-hormone receptor complexes or unliganded receptors is the use of antibodies directed against receptor proteins. We used a monoclonal antibody which has been shown to be specific to D5 antigen, a non-hormone-binding component related to cytosolic oestrogen receptors, and which does not recognise classic type 1 nuclear oestrogen receptor. ${ }^{1}$ The cytoplasmic staining we observed therefore reflected recognition of the ER-D5 antigen which has been shown to be closely related to oestrogen receptors. $^{2}$

Secondly, a study by Coffer et al showed a significant correlation $(p<0.001)$ between D5 immunoradiometric assay (IRMA) value and oestrogen receptor sites in breast tumours assayed by $[3 \mathrm{H}]$ oestradiol binding sites. $^{2}$ However, the correlation between ER-D5 immunohistochemistry and ligandbinding assays for oestrogen receptors has been in dispute $\mathrm{e}^{3-5}$ and as a result the predictive value of the immunocytochemical method using anti-ER-D5 should be interpreted with caution.

Thirdly, the distributors of the antibody (Amersham) indicate that the antigen ER-D5 is present only in oestrogen receptor positive tissues, a finding which was confirmed by King et $a$. $^{6}$

Finally, the aim of our concluding statement was to highlight the importance of identifying the hormone receptors that are biologically active (functional as opposed to non-functional receptors) to predict response to hormonal treatment, because this cannot be assessed by immunocytochemistry alone.

1 Coffer AI, Lewis KM, Brockas AJ, King RJB Monoclonal antibodies against a component related to soluble estrogen receptor. Cancer Res 1985;45:3686-93.

2 Coffer AI, Spiller GH, Lewis KM, King RJB. Immunoradiometric studies with monoclonal antibody against a component related to human estrogen receptor. Cancer Res 1985; 45:3694-8.

3 Horne GM, Angus B, Wright C, et al. Relationships between oestrogen receptor, epidermal growth factor receptor, ER-D5, and P24 oestrogen regulated protein in human breast cancer. J Pathol 1988;155:143-50.

4 Giri DD, Dangerfield VJM, Lonsdale R, et al. Immunohistology of oestrogen receptor and D5 antigen in breast cancer: correlation with oestrogen receptor content of adjacent cryooestrogen receptor content of adjacent cryo-
stat sections assayed by radioligand binding and enzyme immunoassay. J Clin Pathol 1987; and enzyme $734-40$.

5 van der Walt LA, Phillips JI, Afrika DJ. Oestrogen receptor assay by ER-D5 immunocytochemistry fails to correlate with ligand-binding assay in breast cancer. South Afr Med J 1988;74:581-3.

6 King RBJ, Coffer AI, Gilbert J, et al. Histochemical studies with a monoclonal antibody raised against a partially purified soluble estradiol receptor preparation from human myometrium. Cancer Res 1985;45:5728-33.

Secretarial services to consultant microbiologists

A questionnaire on the use of secretarial services sent to 21 consultant microbiologists in Yorkshire in July 1991 produced a 
Percentage of consultants' secretaries giving some help with tasks

\begin{tabular}{lc}
\hline Photocopying & $90 \%$ \\
Word processing & $85 \%$ \\
Telephone & $79 \%$ \\
Audiotyping & $74 \%$ \\
Mail opening & $68 \%$ \\
Diary keeping & $68 \%$ \\
Shorthand & $68 \%$ \\
Organising meetings & $68 \%$ \\
Professional matters arising & $68 \%$ \\
Register of documents & $63 \%$ \\
Filing papers & $63 \%$ \\
Notifying leave arrangements & $63 \%$ \\
Keeping current lists of staff, GPs & $63 \%$ \\
Data input to computer & $58 \%$ \\
Work for outbreak control group & $47 \%$ \\
Travel arrangements & $32 \%$ \\
Supply of tea and coffee & $21 \%$ \\
\hline
\end{tabular}

response from $19(90 \%)$. Of the respondents, $90 \%$ were single consultants in their districts, $26 \%$ having full or part time help from juniors in the specialty; on average each managed a catchment of 64000 specimens a year.

Sixty one per cent had half or less of a secretary's time, most commonly at administrative and clerical grade 3; in all but four cases they had to share their secretary with other consultants. The secretary was located as follows: in the same room as the consultant $(5 \%)$, next door $(26 \%)$, at 25 metres or more away $(32 \%)$, on a different floor $(10 \%)$ and in another building $(5 \%)$. At least $85 \%$ of the secretaries shared accommodation with others, often in small rooms measuring $2 \cdot 5-5$ metres square; $32 \%$ of consultants considered the available space to be insufficient. All had some information technology (IT) equipment but it was considered insufficient in $37 \%$; replies included: "five share one word processor," "one personal computer between four," and "I gave them my home computer".

The amount of help given by secretaries to their consultant was variable (table). Thirty seven per cent of consultants thought that the secretarial provision to deal with these tasks was inadequate, and $37 \%$ thought that they did not, or were unable to, delegate enough of these tasks; $37 \%$ thought that they might benefit from some instruction on how best to work with a secretary.

Arrangements to cover for the secretaries' absence was by cross-cover from other local staff in $\mathbf{7 4 \%}$ of cases, but no cover at all was provided in $10 \%$ of cases; the cover arrangements were considered inadequate by $42 \%$ of consultants.

This small study shows that there are important deficiencies in the provision of secretarial help to consultant microbiologists in Yorkshire and is probably indicative of the position elsewhere in the country. NHS laboratories seemed to fare worse in their general provision than the local public health laboratories, perhaps because of the wider competition they face when arguing for adequate resources. Among the shortcomings found were the generally low levels of secretarial provision to consultants and the often poor location, space, and IT technology available to the secretaries. The curren arrangements seem to be very wasteful of consultants' time; many have difficulties in delegating simple and time consuming tasks and in developing a satisfying working relationship with their secretary, often based so far from their office. These things mus significantly impair the availability and effec- tiveness of our most senior professional staff, and efforts should be made to set them right, particularly as we become more concerned with business efficiency.

There seems to be considerable scope for freeing up consultant time by improving the levels of secretarial support. This is an item that should be assessed and highlighted in the current laboratory audit and accreditation processes.

M BARNHAM Department of Microbiology, Harrogate General Hospital, Harrogate, North Yorkshire HG2 7ND

\section{- \\ BOOK REVIEWS}

All titles reviewed here are available from the BMJ Bookshop, PO Box 295, London WC1H 9TE. Prices include postage in the United Kingdom and for members of the British Forces Overseas, but overseas customers should add $15 \%$ to the value of the order for postage and packing. Payment can be made by cheque in sterling drawn on a United Kingdom bank, or by credit card (Mastercard, Visa or American Express) stating card number, expiry date, and full name.

Lecture Notes on Clinical Investigation. Ed D Maclean, M Bateson, C Pennington. (Pp 229; £11.95.) Blackwell Scientific Publications. 1991. ISBN 0-632-02907-2.

This book is a guide to clinical investigation, a topic that is becoming increasingly importan to today's students and young doctors as the number of investigations necessary to confirm a diagnosis is rapidly increasing. Most textbooks concentrate on the clinical features of a condition and place less emphasis on investigations. In contrast, this book concentrates on the logical investigation of common conditions.

The book is arranged according to the major systems; it gives a short synopsis of the clinical features of the conditions and concentrates on the associated investigations. The indications are given, in addition to a description of the method and interpretation of the results, helped in no small measure by the imaginative use of flow charts.

The book is well written and easy to read, and is a useful addition to the large number of available texts for students. It is also small enough to be carried in a white coat pocket. Although it is aimed primarily at medica students, it would be extremely useful to new house officers and senior house officers studying for the MRCP. Most of the chapters are written from a medical viewpoint, with less emphasis on surgical specialties, so the book is of more use to physicians than surgeons.

In general, it is useful, reasonably priced, and may help students and junior doctors to develop a logical approach to clinical investigation and management.

JANE DACRE

Transfusion Transmitted Infections. Eds DM Smith, RY Dodd. (Pp 344; $£ 75.00)$ Published by the American Society of Clinical Pathologists but distributed by Raven Press. 1991. ISBN 0-89189-289-3.
This is an excellent multiple author book. The chapters are written clearly with sufficient background to interest the "nontransfusionist" and yet they are very comprehensive with valuable references. The title suggests the wide interpretation of the problem: transfusion transmitted infections as opposed to the more general term transfusion transmitted diseases.

Chapter 1, how safe is blood transfusion?" helps to place the problem of infection in the wider perspective. The chapters on basic virology are readable and can be understood by non-virologists. The chapters on donor screening procedures and donor testing would need to be read with caution in the United Kingdom because they refer to policies in the USA, some of which are not implemented in the United Kingdom in a similar manner. The problems are well discussed, however, and the aims of all transfusionists throughout the world are the same.

The book would benefit from more tables. Some paragraphs are difficult to read because of the sheer amount of numerical data which could be better presented in tabloid form. Inevitably, the references, although comprehensive, are already in need of updating.

This is a necessary book in any institution associated with blood transfusion.

V JAMES

Radiopathology of Organs and Tissues. Eds E Scherer, C Streffer, K-R Trott. (Pp 496; 156 figs; DM 448.) Springer. 1991. ISBN 3-540-19091-5.

This volume continues a series entitled Encyclopaedia of Medical Radiology (Handbuch der medizinischen Radiologie). After an introductory chapter on cellular radiobiology there are 14 on specific organs or organ systems and one on the effects of radiotherapy in childhood. Each comprises a detailed, well referenced review of early and late effects of irradiation on normal tissues, both clinically and in experimental models, for which considerable amounts of data are provided. Much of this information, particularly for early reactions, is inevitably derived from animal work. Apart from clinical radiobiological aspects and discussions of pathogenesis, consideration is given to the effects of chemotherapy and combined modalities. Variably detailed histopathological descriptions are provided; these are usually minimally illustrated (save for a detailed chapter on bone and cartilage), although this is not a great deficiency. Earlier references are extensively quoted, but they are also cited up to 1988 and occasionally 1989. The effects of irradiation on tumours does not fall within the scope of the book, but there is a small section on carcinogenesis following childhood irradiation.

This is a comprehensive and well produced volume which, while aimed at (and mostly written by) radiotherapists and radiobiologists, contains quite a lot of experimental pathology, and in spite of the multiplicity of authors good editing has resulted in a satisfying (and rare) uniformity throughout. It is not a diagnostic handbook, but for the pathologist working in a radiotherapy centre, and particularly if he/she is involved in collaborative experimental work, there is useful information not otherwise readily available. 